\title{
A Review of Administrative Reforms in Developing Countries: Why the Limited Success?
}

\author{
Ashiru Olayemi Aliyu \\ Faculty of Economics and Administration \\ University of Malaya, Malaysia \\ Or \\ Department of Politics and Governance \\ Faculty of Humanities, Management and Social Sciences \\ Kwara State University, Malete, Nigeria \\ Kuppusamy Singaravelloo \\ Faculty of Economics and Administration \\ University of Malaya, Malaysia \\ Norma Mansor \\ Faculty of Economics and Administration \\ University of Malaya, Malaysia
}

Received: Mar. 9, 2021 Accepted: May 10, 2021 Online published: May 19, 2021

doi:10.5296/jpag.v11i2.18390～URL: https://doi.org/10.5296/jpag.v11i2.18390

\begin{abstract}
This study survey critical issues that have thwarted administrative reform in the power sector with particular reference to developing countries. The study used endnote software to draw 221 articles from the database of 20 top public administration journals. However, only 86 articles were found useful after carefully sorting, and analysis. This was done to avoid duplication and ensure relevance to the main thrust of this study. Also, practical cases were cited to augment the conceptual and philosophical arguments of notable scholars analyzed. Evidence from the literature revealed that lack of political will and commitments on the part
\end{abstract}


of political actors, bureaucrats often truncates positive reform outcomes. Likewise, the reformers poor stakeholder engagement and mismatch of goals and implementation strategies. It is imperative to unravel problems hampering successful administrative reforms. This paper is important to expand the horizon of knowledge (theoretical knowledge) of current and future academics and practitioners. It also contributes to the literature on public sector management by suggesting pre-conditions for successful reform. This study provides a better understanding of obstacles to purposeful reform outcome in developing countries. Moreover, it also serves as a guide to reform implementers, policy-makers, and practitioners towards purposeful reform outcomes.

Keywords: administrative reforms; bureaucrats; political actors; reform outcomes

\section{Introduction}

Administrative reform is common parlance in public administration and its practice has dominated government activities cross-nationally since the ancient era (Farazmand, 1999). Kroll and Pasha (2019) explain that public organisations have to conduct administrative reform in response to innovation, and stakeholders' demands for better services. Not surprisingly, the practice of administrative reform continues to occupy a central position in governmental activities until modern times. This is because there is increasing demand for better service delivery from citizens, this has put pressure on administrative systems globally (Azizuddin, 2012). From a conceptual perspective, administrative reform is difficult to conceptualise because it means different things to different people. Even amongst scholars, the concept has attracted divergent understanding because different scholars conceived it differently (Caiden, 1991). Interestingly, the core objective is undisputable globally "removing obstacles and fashion out better way of doing things". Administrative reform as an activity has remained a centrepiece in the lives of every nation-state (Liviu, 2015).

Conversely, administrative reforms in public administration are critical to promoting good governance (Sangita, 2002). To provide insight into the discourse on the meaning of administrative reform, this article analyzed different conceptual perspectives. For instance, Caiden (1991: 139) conceived administrative reform as "the artificial inducement of administrative transformation against resistance -has existed over since men conceive better ways of organizing their social activities'. Additionally, Jooste (2008) conceived administrative reform as concerned with improving the efficiency of governance, organizational effectiveness in public administration and capacity building for public service delivery. Similarly, Igbokwe (2017) described administrative reform as a "mechanism for institutional transformation or change, transfusion of innovation, political control and achievement of efficiency and economy".

Although, the conceptual definitions capture the underline principles of every reform initiative. But, for this analysis, this article aligned with Jooste's (2008) conceptual explanation because, the meaning captures the rationale for reform initiatives: restructuring, transformation, and change in the status quo. While acknowledging challenges and difficulties that had characterized the implementation of administrative reform in the power sector, scholars such as (Mendez \& Bachler, 2011; Imasato, Martins \& Pieranti, 2011; 
Neshkova \& Kostadinova, 2012) maintains that its adoption is imperative for any nations that strive to attain sustained growth and national development. Furthermore, the nations continue to face immense pressure to reform as a result of the growing demand for better service by the citizens. It is astonishing to note that, despite the giant strides to engender public governance through persistent administrative reform decades ago, the initiatives in most cases produced an unintended outcome. Generally, scholars have admitted that while administrative reform promise to improve the provision of electricity services but the outcomes are most times counterproductive. Hyden (2013) affirms the existence of serious difficulties and challenges in implementing public sector reform in any environment. Kim and Han (2015) agree that administrative reform often brings unintended consequences. Now, this enviably challenged the scholars to identify forces behind failed attempts to reinvent the public sector delivery system. For instance, Caiden, (2014) asserts that administrative reforms often fail or partially produced the result. While ascribing to Caiden's submission, Peter (1991) affirms that high expectations from the reform activities often amount to disappointments. Similarly, Kim and Han (2015) lessen high expectation from the reform agenda when they submitted that the activity often produces unintended consequences.

Many literature has affirmed that most reforms fail to produce the desired result (Kroll \& Pasha 2019). For instance, Kamaruddin et al., (2017) confirmed that most of the reform initiatives on many occasions did not generate substantial changes. Put simply, they often produce an unsatisfactory result. Ramos, Milanesi, and Ibarra (2021) alluded to the arguments by Caiden, Hyden and Kamaruddin that most reform outcome does not bring expected gain, except for few cases. Consequently, this has exacerbated the quality of services delivered, hence affect livelihood most especially in sub-Sahara Africa. In the context of service delivery, this situation aptly represents what Mundial (1989) described as a crisis of governance (inability of the state to meet the basic needs of the people). Evidently, the UNDP (2018) global human development outlook categorized Norway (0.953); Switzerland (0.944); Australia (0.939); Ireland (0.938); and Germany (0.936) as very high development group. It is saddened that those nations mainly from sub-Sahara Africa such as Burundi (0.417), Chad (0.404), South Sudan (0.388) and Niger (0.354) maintained the bottom in the low (extreme) human development outlook. This anomaly is simply a manifestation of poor service delivery and governance system. It is against this backdrop that this article seeks to examine various factors that had hampered to enviable administrative reform outcome. Notably, Kim and Han (2015) observe that local contexts in which reform initiatives are adopted, interpreted, accepted, legitimated, and concretized for implementation determine their success. Drawing from previous work evaluated, it became clear that there has been limited attention to aggregate critical factors militating against administrative reform initiatives in the power sector. Consequently, aiming to fill this gap, this article aggregates critical factors that have thwarted successive reform initiatives.

\section{Method}

\subsection{Design}

To meet the main thrust of the article, a review of existing literature was undertaking. This 
article analyzed findings of previous research work most especially those that are directly related to the main thrust of this article using a thematic approach. The review relies heavily on the secondary method of data collection.

\subsection{Search Strategy}

The articles searched peer-review journal published in the ISI web of science core collections and EBSCO databases and SCOPUS to access relevant works. Consequently, administrative reforms, reorganisation, restructuring, institutional reforms, and public administration were chosen as dominant keywords based on regional peculiarity. Conversely, all relevant articles were sourced from the database using endnote software. The software tool enables this paper to search and subsequently accessed the original articles. Altogether, the software generated 221 articles from the database of 20 top journals. But, after thorough scrutiny and sorting only 86 articles were found relevant to the subject matter of this analysis and article in particular. The review focused on West African countries and covers from 1989 to 2020. All selected work within this period was painstakingly checked to avoid the likelihood of repetition between two databases. For instance, published materials that directly focused on determinants of successful administrative reform were identified, sorted based on the objective of the studies before been evaluated. Articles that met the inclusion criteria were retrieved and re-examined by researchers. Other article considered irrelevant were subsequently deleted. Additionally, to ensure the credibility and validity of the information, published materials used in the article were derived from the top 20 ranked Journals in public administration and management. Empirical cases were cited to augment the conceptual and philosophical arguments of notable scholars.

\section{Discussions}

\subsection{Political and Bureaucratic Factors}

Although, obstacles to administrative reform are multi-facet. Nonetheless, some causes of failure seem general and where those problems prevailed, administrative reform is unlikely to be successful. Caiden's $(1979 ; 2014)$ work identified the lack of substance in the reform proposal, resources, high level of maladministration, and incessant social conflicts as universal factors. Besides that, the influence of politics on administration cannot be ignored, because the synergy between politics and administration no doubt affects reform outcome. This assertion was reinforced by (Trefon, 2010); McCulloch et al. (2017) who ascribed underestimation of complexities in political culture as obstacles to administrative reform. Most administrative reforms produced unintended outcomes because of the failure to manage local politics (Wilenski,1986). Therefore, the scholars suggested the need to understand the political context within which a reform decision is to be initiated and executed. To put the relationship between politics and reform in a proper perspective, (Bowornwathana 1998, 1999) declared that the success of reforms rests squarely on strong political will.

Equally, Hesse (2005) study alluded to the previous submission by scholars when he identified critical factors that mostly determines successful reform initiatives to include the following: “(1) strong political will and support from elites; (2) logical organization of 
proposed innovation programmes; (3) a reasonable, well-capitulating modernization process; (4) designed innovation within critical policy areas (5) change of attitude of the government, value reorientation, competency, knowledge-driven, improve participation and accountability". Ahmed (2009) standpoint supported the submissions of Hesse (2005) and Andrews (2013), that absence of political will throughout the policy initiation and implementation was found to be responsible for the anomalies for persistent setbacks in the drive to accelerate efficient delivery of basic utilities.

Aside from previous arguments, Bowornwathana (2010) further shed more light on the influence of politics over reform outcome when he asserts that the issue of administrative reform is more political than managerial. It further averred that the issue is seriously influenced by the realities of bureaucratic politics. Concisely, Schedler and Schmucki (2009) emphasized that strong political support is a sine qua non to desirable reform outcome and in most cases lacking. Bennell (1997) offers more insights on contributory factors to limited reform outcomes which amongst others include: lack of commitment on the part of political actors and coupled with strong opposition from vested interest like interest groups, bureaucrats (job security) and labour movements. Beh (2007) share the same viewpoint as Bennell (1997) that a political actor's cooperation is key to attain intended reform outcomes. In the same vein, Seidman (2016) concur with this argument but provided more explanation to buttress Beh's explanation that reform initiatives are likely to fail if not strategically developed because key actors (politicians and bureaucrats) are likely to avoid implementation of reform decisions and policies that threatened their livelihood. To buttress this argument Caiden (1991) affirms that strong political backing, competent insider facilitator and mass support are magical keys to successful reform and when otherwise reform initiatives are deemed to produce an unintended outcome.

Lukamba (2015) found lack of political will as the biggest challenge to successful administrative reform initiative in the Central African Republic. While investigating the political economy of administrative reform in the Central African Republic, Heredia and Schneider (2003) affirm political factors as a vital issue shaping the outcome of reform. Similarly, the study revealed that the nature of the political system adopted in Cameroon was recognized as a stumbling block to effective administrative reform. Moreover, Hyden, (2013) submits that empirical evidence suggests that chances of successful administrative reform in countries where bureaucratic and political elite are fussed are dimmer. More importantly, Friedländer et al., (2021) identify the selfish behaviour of political actors, powerful interest groups and bureaucrats as part of the factors militating against desirable reform outcomes.

In what appears to be an affirmation of earlier submission by previous scholars, Bowornwathana (2010) agreed that administrative reform is usually characterized by a struggle over power between involved actor. In a nutshell, this power struggle enviably explains the pattern of the decision-making process from initiation and execution of administrative reform policies. This might be the reason why Guma (2012) emphasized the imperative of all-inclusive stakeholder's engagement as key to successful reform, and when otherwise the initiative is tantamount to failure. Caiden (2014) summarized other factors to include: geographical such as poor communication; the size of the country; debilitating 
climate, low mobility; physical barriers, and scattered settlement. Thirdly, historical: traditionalism; past reform failures; colonial legacy; biculturalism. Fourth, culture, diversities; indiscipline; tribalism; corruption; paralysis of public will, religious fundamentalism and linguistic barriers. Lastly, low managerial skill; monopoly, rigid bureaucracy; low saving and investment. Meyer-Sahling and Yesilkagit (2006) affirm that trust deficit in government, inability to build consensus amongst the stakeholders was recognized as a good reason for the unintended outcome.

Thompson's (1999) study has earlier expressed apprehension over behaviours of the reformer as a determinant of positive reform outcome. Interestingly, Caiden's viewpoint on politicians and bureaucrat's disposition towards reform initiatives have lessened the high expectation and remain valid until today. He rightly observed that "public leaders were careful to give much lip service to administrative reform but they were careful to select only those which did not threaten their power, standing, and popularity and therefore serve to reinforce existing institutions and arrangement and preclude viable alternatives (Caiden, 1990). Similarly, Fernandez and Raineg (2006) strongly believe that support and unwavering commitment of top bureaucrats are vital to a successful transformation of public organization. Recently, Kroll and Pasha (2019) identify cynicism as a key obstacle to successful reform. Kroll and Pasha argued that although reform comes in varying sizes and shapes but are venerable to failure because of cynicism and scepticism of worker on the positive effect of the reform on the organisation. To buttress the earlier argument, Cheung (2020) also agreed that despite similarities in the reform rhetoric, vision and tools there exist a variation attributable to institutional, historical, cultural and political factors. Beyond that, Cheung believes these factors relate to reform politics. As not reform can be devoid of political order and this largely relates to the interaction between the politicians and bureaucrats.

\subsection{Lack of Consultations and Non-inclusion of Stakeholders}

Muhammed (2012) stressed that successful government administrative reform has not achieved far-reaching results because they worked in isolation and secrecy and did not provide an avenue for the active participation of key stakeholders in the implementation process. This assertion was further corroborated by Caiden's (1979) study where he reported that administrative reform had no substantial impact, not that the strategies are incorrect, wrong, or implemented by unqualified reformers but because of inadequate support from key stakeholders. When this happened the reformer has to battle stiff resistance and overwhelmingly odds, and of course, the activities became emasculated. This led the UN (2015) to reiterates the significance of all-inclusive synergy amongst stakeholders in the implementation process to the actualization of reform objectives. This drive would not only facilitate the realisation of the proposed restructuring but also build ownership, public accountability, transparency, public confidence, and trust in the reform exercise hence, positively affect reform outcome. Sangita (2002) summarizes this argument thus: "the success of administrative reform depends upon the government's ability to present strategic reform based on the vision in consultation with the wider sections of the society as well as effective communication to the stakeholders and people about the need for reform and likely benefits from it". Asatryan et al (2017) submission corroborate Sangita's assertion that 
positive reform outcomes depend on the level of stakeholders' engagement. This suggests that a good reform initiative should seek strategic engagement between the reformer and vested interest/parties. But, when otherwise the reform is unlikely to be successful.

\subsection{Weakened Institutions}

From another perspective, Damar's (2008) study drew attention to the widening gap between the rhetoric of reformer and the reality of implementation due to poor understanding of reform strategies by the implementers. Consequently, this mismatch has thwarted predetermined reform objectives and contribute to the intended outcome. Conversely, this argument was enviably supported by the following scholars (Ellinas \& Suleiman, 2008; Pollitt \& Buckaert, 2004; Levy, 2000; Cini, 2004; Khan, 2011). Alex (2006) summarizes problems associated with successive reforms which entail poor leadership, political instability, excessive government interference, lack of accountability, and inadequate power devolution to the ties of government from central government. From another perspective, Mbah (2016) stressed the importance of administrative reform and agreed that economic and political development largely depends on a functional administrative system. He further averred that this is imperative to attain the developmental preference and needs of the populace. In addition to what has been discussed earlier by Riggs (1993) in Guma (2012) asserts that administrative reform in Africa is susceptible to failure because of a distinctive set of parochial, ethnocentric ideas and practices. In this sense, it would be extremely difficult to dismiss this argument in its entirety, as administrative practices depend on the norms and cultural practices of the society. Alberts, Davila, and Valenzuela (2021) in their submission also subscribed to the argument that weak institutions have remained one of the banes of purposeful public sector reform.

\subsection{External Pressure and Its Implication}

Zamor and Khator (1994)) argued that most of the reform initiatives in developing countries are foreign induced (external pressure by IMF or World Bank) that lack local content. This amply creates suspicions and the reform agenda was frustrated by vested interest amongst the populace. For instance, Bowornwathana (2014) reported cases where reformers assumed that an already-made strategy for the global reform paradigm can easily be replicated, the result revealed a contradiction between assumption and realities. The implication is that the citizen did not benefit from the public reform initiatives. Scholars have strongly argued whether there is a generally acceptable global reform paradigm (Kaul, 1996).

Alongside this argument, scholars (Rhodes, 1996; Kaul, 1996; Pollitt \& Summa, 1997) are unconvinced that a country's successful reform model can be automatically replicated and anticipate instant success. To further corroborate this argument, Schick (1998) warned that despite the success of New Zealand administrative reform, this model cannot be emulated by other countries because of different administrative traditions. From Bowornwathana's empirical case coupled with Rhodes; Pollitt and Summa, likewise Schick, it is evident that most countries are not guided by these vital empirical cases and hypotheses. Perhaps, this might be responsible for the historic failure of administrative reform in most African countries which have high incidences of foreign induced policies including administrative 
reform.

\section{Conclusion}

No doubt there is growing interest in administrative reform because of increasing pressure for improved service delivery globally. However, evidence from different scholars revealed the multi-faceted nature of obstacles to administrative reform. The dimensions of the problems are twofold: firstly, universal, and seem specific. Drawing from the results it is obvious that the unsatisfactory living condition of people in any country is a product of poor governance and administrative system. Thus, there seems to be a consensus amongst scholars that the administrative system can only be successful when there is strong political will and commitment of key actors.

Likewise, the ability of the reformer to understand the political culture of the local environment. Moreover, nations with a history of foreign induced policies and incidences of external pressure to reforms are vulnerable to unintended reform outcomes. This is not unexpected, as the contents of the reform strategy might offend their administrative and political culture, therefore, the reformer battle implementation odds as a result of strong resistance from vested interest. In all, factors identified and analyzed in the result section can be considered critical issues that determine a successful administrative reform or otherwise. Although, the result and discussion in this article were based on previous work analysed. Therefore, to establish more facts, future empirical research could be conducted to ascertain whether this finding still valid.

Although, this article analyzed submissions from scholars on hindrances to impactful administrative reform. However, their submissions have not been empirically tested to understand the country's peculiar cases. Nevertheless, evidence suggests that inclusive administrative reform strategies must be developed to adequately respond to these specific obstacles. The thrust of this article hopes to contribute to the debate on improving the public service delivery system. Also, to enrich the body of literature, and broaden the knowledge of reformers, policymakers and administrators. The article aggregates common impediments to satisfactory administrative reform. As nations strive to strengthen their administrative system to accomplish national objectives, critical issue of this nature cannot be handled with levity. It is not an overstatement to say that administration paves the way for good governance which depicts effective, efficient, responsive, and citizen's friendly delivery of public goods and services (World Bank, 1997; Putnam, 2000). Interestingly, these ingredients of good governance cannot be achieved without a successful administrative reform.

\section{Acknowledgements}

All authors contributed equally to the contemplation and design of the study. Funding: This study receives no specific financial support. Competing Interest: The authors declare that there is no conflicting interest regarding the publication of the paper. 


\section{References}

Ahmed, N. (2009, September). Institutional reforms in water supply arrangements in Karachi. In Proceedings of the Institution of Civil Engineers-Municipal Engineer (Vol. 162, No. 3, pp. 171-178). Thomas Telford Ltd.

Andrews, M. (2013). The limits of institutional reform in development: Changing rules for realistic solutions. Cambridge University Press.

Asatryan, Z., Heinemann, F., \& Pitlik, H. (2017). Reforming the public administration: The role of crisis and the power of bureaucracy. European Journal of Political Economy, 48, 128-143. https://doi.org/10.1016/j.ejpoleco.2016.08.004

Azizuddin, M. (2012). Public Administration Reform: A Perspective on Theoretical Challenges, Society \& Change, 6(3), 68-78.

Beh, L. (2007, August). Administrative Reform: Issues of Ethics and Governance in Malaysia and China [Conference session]. International China World Conference at the Institute of China Studies, University of Malaya, Malaysia.

Bennell, P. (1997). Privatization in sub-Saharan Africa: Progress and prospects during the 1990s. World Development, 25(11), 1785-1803. https://doi.org/10.1016/s0305-750x(97)00068-5

Bowornwathana, B. (1999). Administrative Reform and the Politician-Bureaucrat Perspective: Visions, Processes, and Support for Reform. In Handbook of Comparative Public Administration in the Asia-Pacific, (p. 69-77). Marcel Dekker.

Bowornwathana, B. (2006). Transforming bureaucracies for the 21st century: The new democratic governance paradigm. In Comparative Public Administration (pp. 667-679). Emerald Group Publishing Limited.

Bowornwathana, B. (2013). Governance reform in Thailand: Questionable assumptions, uncertain outcomes. Asia Pacific Journal of Public Administration, 35(2), 149-165. https://doi.org/10.1080/23276665.2013.10800987

Bowornwathana, B., \& Poocharoen, O. (2010). Bureaucratic politics and administrative reform: Why politics matters. Public Organization Review, 10(4), 303-321. https://doi.org/10.1007/s11115-010-0129-0

Bowornwathana, B. (1998). Bangkok Metropolitan Administration into the Twenty-First Century: The Practice of Good Local Governance (31). Metropolitan Governance and Planning in Transition: Asia-Pacific Cases, United Nations Centre for Regional Development.

Caiden, G. E. (1979). Administrative reform: A view from the field. Policy Studies Journal, 8(3), 456-462. https://doi.org/10.1111/j.1541-0072.1979.tb01252.x

Caiden, G. E. (1991). Administrative Reform Comes of Ages. W. de Gruyter.

Caiden, G. E. (2014). Administrative reform comes of age. Walter de Gruyter GmbH \& Co KG. 
Cheung, A. B. (2020). Administrative Reform: Opportunities, Drivers, and Barriers. In Oxford Encyclopedia of public administration.

Cini, M. (2004). The reform of the European Commission: An ethical perspective. Public Policy and Administration, 19(3), 42-54. https://doi.org/10.1177/095207670401900305

Damar, M. (2008). Administrative Reform within the European Union [Unpublished doctoral dissertation]. School of Management and Governance, University of Twente, The Netherlands.

Ellinas, A., \& Suleiman, E. (2008). Reforming the commission: Between modernization and bureaucratization. Journal of European Public Policy, 15(5), 708-725. https://doi.org/10.1080/13501760802133179

Farazmand, A. (1999). Administrative reform in global perspectives: A symposium. International Journal of Public Administration, 22(6), 805-813. https://doi.org/10.1080/01900699908525405

Fernandez S., \& Rainey, H. G. (2017). Managing successful organizational change in the public sector. In Debating Public Administration (pp. 7-26). Routledge.

Friedländer, B., Röber, M., \& Schaefer, C. (2021). Institutional Differentiation of Public Service Provision in Germany: Corporatization, Privatisation and Re-Municipalisation. In Public Administration in Germany (pp. 291-309). Palgrave Macmillan, Cham.

Gboney, W. K., Cubbin, J., \& Dassiou, X. (2009, August). Empirical Assessment of the Impact of Power Sector Reforms in Africa: A Study of the Generation, Transmission, and Distribution Sectors [Paper presentation]. The ASME 2008 2nd International Conference on Energy Sustainability collocated with the Heat Transfer, Fluids Engineering, and 3rd Energy Nanotechnology Conferences, Jacksonville, Florida, USA.

Guma, P. K. (2012). Three decades of orthodox approaches to administrative reform in Africa: The Ugandan experience. SSRN Electronic Journal. https://doi.org/10.2139/ssrn.2097123

Hesse, J. J. (2005, May). The Korean Modernization Process-Looked at from Abroad [Paper presentation]. Sixth Global Forum on Reinventing Government.

Igbokwe, I. I. (2017). The administrative reforms experience in Nigeria. IOSR Journal of Humanities and Social Science, 22(06), 10-19. https://doi.org/10.9790/0837-2206121019

Imasato, T., Martins, P. E., \& Pieranti, O. P. (2011). Administrative reforms and global managerialism: A critical analysis of three Brazilian state reforms. Canadian Journal of Administrative Sciences / Revue Canadienne des Sciences de l'Administration, 28(2), 174-187. https://doi.org/10.1002/cjas.163

Jooste, S. F. (2008). A new public sector in developing countries. Collaboratory Research on Global Projects, Ortega. Standford University.

Kamaruddin, K., Prasojo, E., Rahayu, A. Y. S., \& Jannah, L. M. (2017). Determinants of Successful Administrative Reform A Case in Indonesian National Institute of Public Administration. Paper presented at the 1st International Conference on Administrative 
Science, Policy and Governance Studies (ICAS-PGS 2017) and the 2nd International Conference on Business Administration and Policy (ICBAP 2017).

Kaul, M. (1996). undefined. Public Administration and Development, 16(2), 131-150. https://doi.org/10.1002/(sici)1099-162x(199605)16:23.0.co;2-b

Killian, J., \& Eklund, N. (2008). Handbook of administrative reform: an international perspective: In Levy, R. (2000), Implementing European Union Public Policy. Cheltenham, Edward Elgar CRC Press.

Khan, M. M. (2013). Khan, M. M. (2013). Public Administration in the Governance Framework. Journal of Asiatic Society, 58(2), 277-288

Kroll, A., \& Pasha, O. (2019). Managing change and mitigating reform cynicism. Public Money \& Management, 1-9. https://doi.org/10.1080/09540962.2019.1683982

Liviu, R. (2015). How to develop sustainable public administration reforms. Transylvanian Review of Administrative Sciences, 11(44), 180-195. https://doi.org/10.24193/tras.2017.0010

Mbah, P. O. (2016). The Neoliberal state and administrative reforms in Nigeria. Afro Asian Journal of Social Science, 7(3), 1-30.

McCulloch, N., Sindou, E., \& Ward, J. (2017). The political economy of aid for power sector reform. IDS Bulletin, 48(5-6). https://doi.org/10.19088/1968-2017.168

Mendez, C., \& Bachtler, J. (2011). undefined. Journal of European Public Policy, 18(5), 746-765. https://doi.org/10.1080/13501763.2011.586802

Meyer-Sahling, J. (2006). undefined. Journal of Communist Studies and Transition Politics, 22(3), 274-297. https://doi.org/10.1080/13523270600855662

Muhammed, M. (n.d.). Public Administration Reform: A Perspective on theoretical Challenge. Society and Change, 6(3), 68-78.

Neshkova, M. I., \& Kostadinova, T. (2012). The effectiveness of administrative reform in new democracies. Public Administration Review, 72(3), 324-333. https://doi.org/10.1111/j.1540-6210.2011.02483.x

Pollitt, C., \& Bouckaert, G. (2004). Public Management Reform: A Comparative Analysis. Oxford University Press.

Pollitt, C., \& Summa, H. (1997). Trajectories of reform: Public management change in four $\begin{array}{lllll}\text { countries. } \quad \text { Public } \quad \text { Money } \quad \text { Management, } & \text { 17(1), }\end{array}$ https://doi.org/10.1111/1467-9302.00051

Putnam, R. D. (2000). Bowling alone: The collapse and revival of American community. Simon \& Schuster.

Ramos, C., Milanesi, A., \& Ibarra, D. G. (2021). Public Administration in Uruguay: Modernization in Slow Motion. In B. G. Peters, C. A. Tercedor, \& C. Ramos (Eds.), The 
Emerald Handbook of Public Administration in Latin America (pp. 229-258): Emerald Publishing Limited. doi.org/10.1108/978-1-83982-676-420201010

Rhodes, R. A. W. (1996). The new governance: governing without government. Political Studies, 44(4), 652-667. https://doi.org/10.1111/j.1467-9248.1996.tb01747.x

Riggs, F. (1963). Bureaucratic and Political Development; a Paradoxical view. In Joseph la Palombara ed Bureaucracy and Political Development, Princeton NJ: Princeton

Sangita, S. (2012). Administrative reforms for good governance. The Indian Journal of Political Science, 6(4), 325-350.

Schedler, K., \& Schmucki, L. (2009). The political rationale of administrative reforms: Parliamentary support of output control in Switzerland. Swiss Political Science Review, 15(1), 1-30. https://doi.org/10.1002/j.1662-6370.2009.tb00121.x

Schick, A. (1998). Why Most Developing Countries Should Not Try New Zealand's Reforms. The World Bank Research Observer, 13(1), 123-131. https://doi.org/10.1093/wbro/13.1.123

Seidman, A. (2016). State and law in the development process: Problem-solving and institutional change in the third world. Springer.

Thompson, J. R. (1999). Devising administrative reform that works: The example of the reinvention lab program. Public Administration Review, 59(4), 283-292. https://doi.org/10.2307/3110111

Trefon, T. (2010). Administrative obstacles to reform in the Democratic Republic of Congo. International Review of Administrative Sciences, 76(4), 702-722. https://doi.org/10.1177/0020852310381213

UNDP. (2018). Human Development Indices and Indicators: 2018 Statistical Update, UNDP, New York

Wilenski, P. (1986). Administrative reform? General principles and the Australian experience. Public Administration, 64(3), 257-276. https://doi.org/10.1111/j.1467-9299.1986.tb00621.x

World Bank. (1989). Sub-Saharan Africa: From crisis to sustainable growth: a long-term prospective study.

World Bank (1997a), World Development Report: State in the Changing, World, Oxford University Press: World Bank.

World Bank Group (1997b). Annual Meetings World Bank Group Issue Brief Corruption and Good Governance. Oxford University Press: World Bank.

Zamor, J. C., \& Khator R. (1994). Public Administration in the Global Village. Praeger. 


\section{Copyright Disclaimer}

Copyright for this article is retained by the author(s), with first publication rights granted to the journal.

This is an open-access article distributed under the terms and conditions of the Creative Commons Attribution license (http://creativecommons.org/licenses/by/4.0/). 